\title{
BUDOWA I WIEK WYŻSZEJ TERASY KAMIONKI NA ODCINKU SUCHEDNIÓW-REJÓW
}

\author{
Sediments and age of Kamionka River higher terrace between Suchedniów and Rejów
}

\author{
TOMASZ KALICKI*, PAWEŁ PRZEPIÓRA, ŁUKASZ PODRZYCKI
}

\begin{abstract}
Zarys treści. Przedstawiono strukturę, teksturę i wiek osadów budujących terasę wyższą $(5-12 \mathrm{~m})$ Kamionki pomiędzy Suchedniowem i Rejowem. Te piaszczysto-żwirowe aluwia korytowe, poziomo, przekątnie i rynnowo warstwowane, były składane przez rzekę roztokową w okresie kataglacjalnym stadiału warty (datowania TL: 127-119 ka). Ich uziarnienie i struktura są różne w rozszerzeniach i zwężeniach doliny, co uwarunkowane było zmienną energią przepływów i zróżnicowaniem subśrodowisk sedymentacji fluwialnej. W przełomowym odcinku doliny aluwia zostały przykryte przez bardzo gruboklastyczne osady proluwialne. W vistulianie (czynnik klimatyczny) i w ostatnich stuleciach (czynnik antropogeniczny) powierzchnia tej terasy uległa zwydmieniu.
\end{abstract}

Słowa kluczowe: Góry Świętokrzyskie, terasa Kamionki, stadiał warty, sedymentologia, datowania TL

\begin{abstract}
The structure, texture and age of the sediments of the higher (5-12 m) terrace of the Kamionka river between Suchedniów and Rejów are presented. These horizontal and cross-bedded sandy-gravel channel alluvia were accumulated by a braided river during the end of the Wartanian stadial (TL datings: 127-119 ka). Their grain size and structure differ in the wide and narrow sections of the valley, which was caused by changes of flow energy and differentiation of sedimentological fluvial subenvironments. Alluvia were covered by very coarse colluvia in the gap section. Dunes formed on top of the terrace in the Vistulian (climatic factor) and the last centuries (anthropogenic factor).
\end{abstract}

Key words: Holy Cross Mountains, terrace of Kamionka River, Wartanian stadial, sedimentology, TL datings

\section{Wstęp - rys paleogeograficzny}

Góry Świętokrzyskie charakteryzują się promienistym, odśrodkowym układem sieci rzecznej. Na północ płyną cieki dorzecza Kamiennej a na południe rzeki zlewni Nidy. Został on zdeterminowany przez utworzenie w czasie ruchów alpejskich na przełomie kredy i paleogenu wielkopromiennego wyniesienia o osi NW-SE skał mezozoicznych ponad paleozoicznym trzonem (Lencewicz 1913; Kowalski 2002b). Rzeki, dostosowując się do tej struktury, rozcinały pokrywę mezozoiczną oraz trzon paleozoiczny niezależnie od odporności skał i utworzyły przełomy poligenetyczne (najczęściej epigenetyczno-antecedentne). Układ dolin północno-wschodniego obrzeżenia Gór Świętokrzyskich (m.in. Kamionki) uwarunkowany jest kierunkiem spękań ciosowych (Kosmowska-Suffczyńska 1966, 2000), a na lokalny, odśrodkowy lub dośrodkowy, układ sieci rzecznej wpływały dodatkowo węzły geodynamiczne, z których jeden, suchedniowski, znajduje się na obszarze badań (Kowalski 2002b).

Czwartorzędowy etap ewolucji dolin był w plejstocenie związany ze zlodowaceniami (np. Czarnocki 1927, 1931; Lencewicz 1934; Samsonowicz 1934; Klimaszewski 1952; Radłowska 1957, 1960, 1963; Łyczewska 1959, 1971; Klatka 1964; Różycki 1964, 1972; Mycielska-Dowgiałło 1969, 1972; Lindner 1971, 1979, 1980, 1984a, b, 2004, 2005; Bartosik 1972; Hakenberg, Lindner 1971, 1973; Ber i in. 2007; Lindner, Marks 2012) oraz rozwijającym się tu przynajmniej trzykrotnie środowiskiem peryglacjalnym (Mojski 2005). Znaczne deniwelacje powodowały piętrowość zjawisk (Klatka 1955, 1968) i zasypywanie preglacjalnych dolin przez osady stokowe i fluwioglacjalne, a w efekcie brak złożonych systemów terasowych (Różycki 1972) charakterystycznych dla innych dolin „obszaru peryglacjalnego” (Mojski 1993).

\footnotetext{
* Uniwersytet Jana Kochanowskiego w Kielcach, Instytut Geografii, Zakład Geomorfologii, Geoarcheologii i Kształtowania Środowiska, ul. Świetokrzyska 15, 25-406 Kielce; e-mail: tomaszkalicki@ ymail.com
} 
Lądolody południowopolskie (san I, san II) wkroczyły na obszar Gór Świętokrzyskich (Mojski 2005), których rzeźba, w tym przełomy rzeczne, uległa przekształceniu glacjalnemu (Kowalski 1988, 2002b). Na początku interglacjału mazowieckiego odpreparowana została starsza rzeźba, tzn. kuesty z subsekwentnymi dolinami u ich podnóża $\mathrm{w}$ mezozoicznym obrzeżeniu gór (Różycki 1967) i przełomy rzeczne $w$ trzonie paleozoicznym (Lencewicz 1913; Kowalski 1988). Erozja interglacjalna przybrała bardzo duże rozmiary, w dolinach północnego obrzeżenia dotarła do skalnego podłoża podczwartorzędowego, co mogło być spowodowane epejrogenicznym podnoszeniem NE przedpola Gór Swiętokrzyskich (Radłowska 1963; Gilewska 1972).

Nasunięcie lądolodu odry nawiązywało ściśle do orografii. Loby wkraczały tylko w obniżenia, a zabarykadowane doliny i kotliny były intensywnie zasypywane (do wysokości 260-270 m n.p.m.) przez osady fluwioglacjalne oraz rzeczne zazębiające się z pokrywami soliflukcyjnymi. W fazie maksymalnej (stadiał kamiennej) jeden z nich zajął dolinę górnej Kamiennej (Samsonowicz 1925; Różycki 1967; Lamparski 1970; Lindner 1970, 1984a, 1988, 2004, 2005; Filonowicz 1971a, b; Bartosik 1972; Mojski 2005) i wkroczył do doliny Kamionki dwoma lobami: od wschodu (doliną Łosiennicy) i od północy przez przełom Kamionki poniżej Suchedniowa. Oba jęzory rozdzielone były nunatakiem Kamiennej Góry oraz strefą akumulacji międzylobowej i łączyły się w miejscu współczesnego ujścia Łosiennicy do Kamionki. Lądolód zajął dolną, środkową i częściowo górną część zlewni Kamionki, a wody proglacjalne, które były odprowadzane na południe oraz na wschód przez kotlinę Mostki, wypełniły obniżenia miąższymi osadami fluwioglacjalnymi (Gilewska 1972; Lewandowski i in. 1975). Sladem arealnego wytapiania lobów lądolodu odry są terasy kemowe (5 poziomów według Lewandowskiego i in. 1975; 4 poziomy według Przepióry 2017) zachowane w morfologii środkowego odcinka doliny Kamionki i dolinie Łosiennicy.

W ociepleniu pomiędzy stadiałami odry i warty następowało rozcinanie osadów wypełniających doliny i formowanie teras (Lindner 1970). W dolinach Lubrzanki oraz Belnianki powstała terasa o wysokości 10-12 m (Klatka 1962), w dolinie Czarnej Nidy terasa III (8-10 m) (Krupa 2013, 2015), w dolinie środkowej Nidy terasa IV (10-15 m) (Hakenberg, Lindner 1971), a w dolinie Kamionki terasa G III (5-12 m) (Lewandowski i in. 1975).
Ochłodzenie vistuliańskie spowodowało, że region świętokrzyski znalazł się ponownie w klimacie peryglacjalnym, $\mathrm{z}$ dominującym wietrzeniem mrozowym i soliflukcyjnym przemieszczaniem powstałych pokryw gruzowych (Klatkowa 1955). Intensywne ruchy masowe prowadziły do odgrzebywania starych progów strukturalnych i monoklinalnych (Radłowska 1963). W dnach dolin zachodziła akumulacja aluwiów piaszczysto-żwirowych zazębiających się z dwoma soliflukcyjnymi pokrywami gruzowymi, nadbudowującymi terasy środkowopolskie (Klatkowa 1955; Klatka 1955). W ujściowym odcinku doliny Czarnej Nidy i w dolinie środkowej Nidy z okresem vistulianu wiązana jest terasa III (78 m) (Hakenberg, Lindner 1971, 1973), a w dolinie Czarnej Nidy na kilku stanowiskach aluwia terasy II (4-6 m) były datowane metodą TL na okres 25-16 ka (Krupa 2013, 2015). Datowania TL wskazują, że aluwia terasy o wysokości 5-16 m w dolinie Belnianki (Ludwikowska-Kędzia 2005, tam literatura) i terasy wysokiej $(8-14 \mathrm{~m})$ w dolinie Lubrzanki (Kowalski 2002a) pochodzą z pleniglacjału (stadiał świecia oraz interstadiał grudziądza). W dolinie Kamionki terasa G IV wiązana była ze zlodowaceniem bałtyckim (Lewandowski i in. 1975). Na rozciętych w starszym dryasie (Klatka 1968) lub allerødzie (Hakenberg, Lindner 1971) i zdrenowanych terasach vistuliańskich powstały w późnym glacjale liczne wydmy (Czarnik 1966; Jaśkowski 1996), współcześnie często zniwelowane antropogenicznie (Przepióra 2017). Ze schyłkiem plejstocenu wiązany jest rozległy poziom o wysokości 3-4 m (terasy II wg Hakenberga, Lindnera 1971, 1973; terasa I wg Krupy 2013) zachowany w kilku odcinkach Czarnej Nidy i utworzony przez rzekę roztokową w młodszym dryasie. Młododryasowy wiek tej terasy potwierdza data $10480 \pm 70$ BP (10 658-10 156 cal. BC; MKL-3453), uzyskana dla subfosylnego pnia sosny zalegającego in situ $\mathrm{w}$ piaszczysto-żwirowych osadach korytowych rzeki roztokowej, budujących również poziom o podobnej wysokości w dolinie Czarnej Koneckiej (Nowak 2017). Poziomy te zostały rozcięte na przełomie młodszego dryasu i holocenu (Klatka 1968; Hakenberg, Lindner 1971, 1973) przez rzeki płynące wielkimi meandrami (Krupa 2013, 2015), które zachowały się w brzeżnych częściach równin zalewowych, w licznych dolinach świętokrzyskich (Kalicki i in. 2016), w tym w dolinie Kamionki (Przepióra 2017).

\section{Cel i metody badań}

Jak pokazuje przedstawiony powyżej stan badan, rozpoznanie systemów terasowych $\mathrm{w}$ re- 
gionie świętokrzyskim jest słabe, zarówno jeśli chodzi o strukturę i teksturę aluwiów, jak i wiek poszczególnych poziomów. Celem artykułu jest rozszerzenie tej wiedzy w oparciu o badania odcinka doliny Kamionki pomiędzy Suchedniowem i Rejowem (rys. 1). Studia koncentrowały się na określeniu zróżnicowania litofacjalnego i litogenetycznego oraz wieku aluwiów. Wyniki badań pozwoliły na odtworzenie warunków paleogeograficznych $\mathrm{w}$ okresie formowania się osadów terasy.

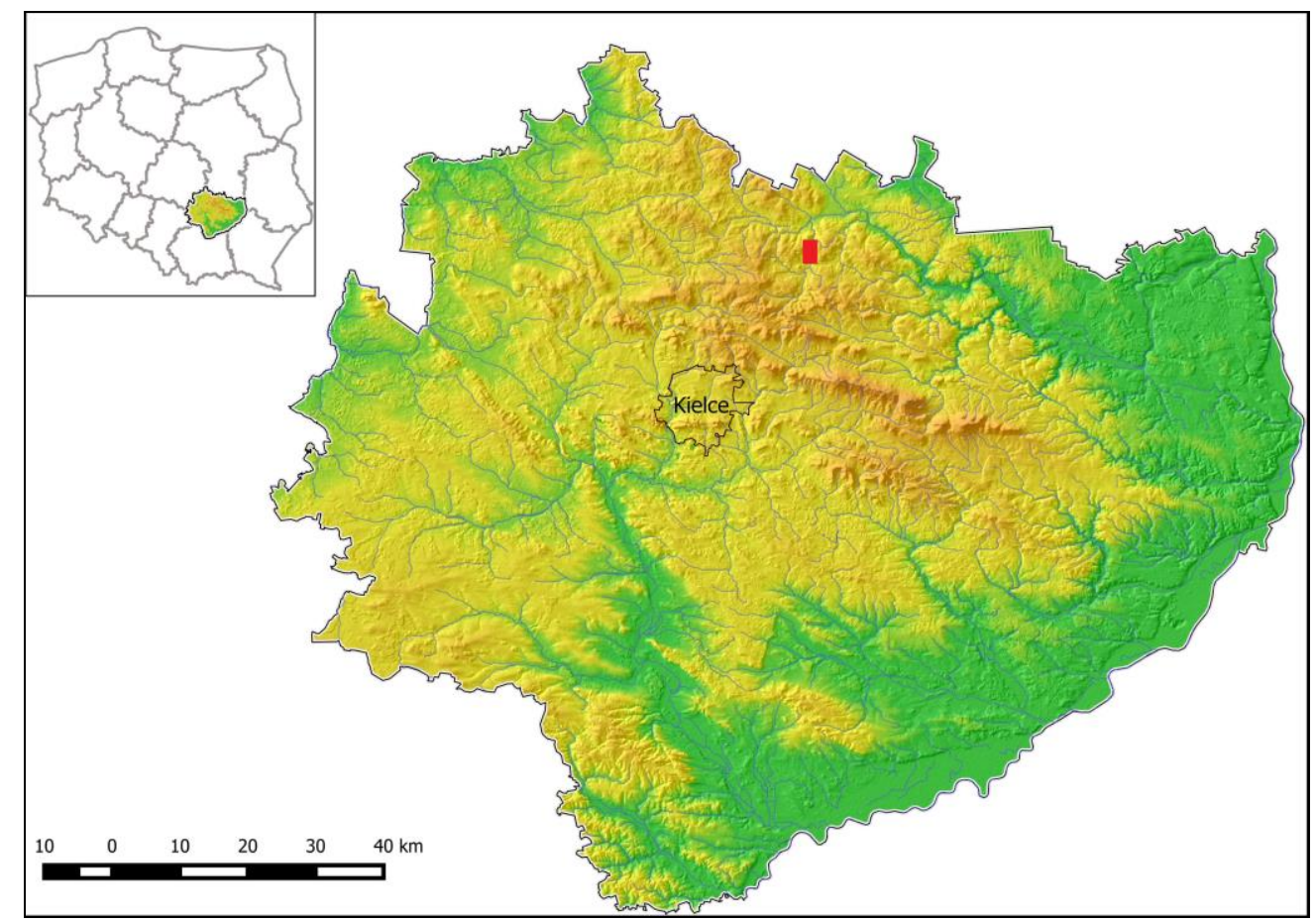

Rys. 1. Położenie obszaru badań na numerycznym modelu terenu (NMT) województwa świętokrzyskiego (oprac. P. Przepióra, M. Frączek)

The location of the study area on a digital terrain model (DTM) of the Świętokrzyskie voivodship (by P. Przepióra, M. Frączek)

W trakcie kartowania geomorfologicznego (rys. 2) do badań szczegółowych wytypowano dwa profile oddalone od siebie o $1,5 \mathrm{~km}$. W celu uchwycenia lokalnego zróżnicowania w wykształceniu aluwiów jeden z profili reprezentuje obszar rozszerzenia $\mathrm{w}$ rejonie Suchedniowa, natomiast drugi odcinek przełomowy powyżej zalewu w Rejowie. W profilach, wykonanych metodą schodkową, zastosowano opis i analizę litofacjalną i litogenetyczną opartą na pracach Zielińskiego $(1998,2014)$. Pobrano próbki na analizy uziarnienia, a z kluczowych warstw wzięto również próbki na datowania termoluminescencyjne (3-4 próbki z każdego profilu).

Wszystkie analizy granulometryczne i datowania zostały wykonane w Zespole Laboratoriów Naukowo-Dydaktycznych Instytutu Geografii UJK w Kielcach. Do analiz uziarnienia (próbki o wadze
100 g) wykorzystany został zestaw sit (DIN ISO $3310 / 1$, sita: $2,8 \mathrm{~mm}, 2,5 \mathrm{~mm}, 2,0 \mathrm{~mm}, 1,6 \mathrm{~mm}$, $1,4 \mathrm{~mm}, 1,0 \mathrm{~mm}, 800 \mu \mathrm{m}, 630 \mu \mathrm{m}, 500 \mu \mathrm{m}, 400$ $\mu \mathrm{m}, 315 \mu \mathrm{m}, 250 \mu \mathrm{m}, 200 \mu \mathrm{m}, 160 \mu \mathrm{m}, 125 \mu \mathrm{m}$, $100 \mu \mathrm{m}, 90 \mu \mathrm{m}, 63 \mu \mathrm{m},<63 \mu \mathrm{m})$ i przesiewaczy „Retsch - Rahmen”, a dla najgrubszych osadów zestaw sit (sita: $32,0 \mathrm{~mm}, 16,0 \mathrm{~mm}, 10,0 \mathrm{~mm}, 8,0$ $\mathrm{mm}, 5,0 \mathrm{~mm}, 4,0 \mathrm{~mm}, 2,5 \mathrm{~mm}, 2,0 \mathrm{~mm},<2,0 \mathrm{~mm}$ ) i wytrząsarka „Multiserw-Morek” LpzE-2e. Wyniki przedstawiono $\mathrm{w}$ formie graficznej $\mathrm{w}$ programie „GRANULOM”, dla wszystkich próbek zostały wyliczone wskaźniki uziarnienia Folka-Warda (1957): średnia średnica ziarna (Mz), odchylenie standardowe $\left(\delta_{\mathrm{I}}\right)$ określające wysortowanie osadu, skośność $\left(\mathrm{Sk}_{\mathrm{I}}\right)$ oraz kurtoza $\left(\mathrm{K}_{\mathrm{G}}\right)$. Datowania termoluminescencyjne (TL) wykonano na czytniku „MAZAR-01” oraz czytniku TL „Laboratory Leader-Analyser RA'04” firmy „Microlab”. 


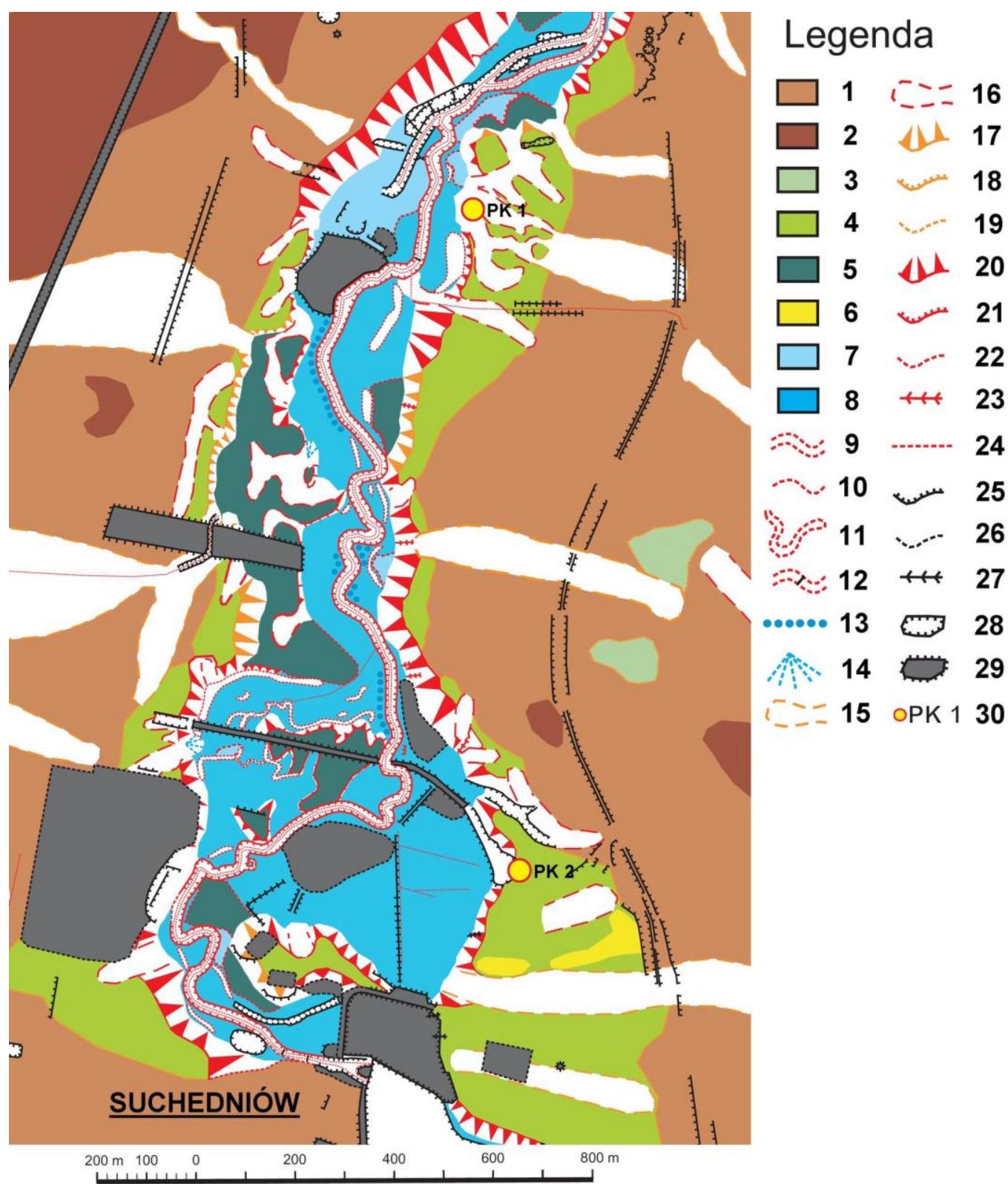

Rys. 2. Mapa geomorfologiczna doliny Kamionki poniżej Suchedniowa (oprac. P. Przepióra)

1 - stok łagodny $\left(2-6^{\circ}\right) ; 2$ - stok stromy (powyżej $\left.6^{\circ}\right) ; 3$ - terasa kemowa; 4 - wyższa $(5-12 \mathrm{~m})$ terasa fluwialna, stadiał warty; 5 - niższa (3-4 m) terasa fluwialna, zlodowacenie wisły; 6 - wydma; 7 - wyższa (2-2,5 m) równina zalewowa, holocen; 8 - niższa (1-1,5 m) równina zalewowa, holocen; 9 - główne koryto rzeczne, aluwialne; 10 - drugorzędne koryto rzeczne, aluwialne; 11 - paleomeander holoceński; 12 - próg i jaz na rzece; 13 - wał przykorytowy; 14 - stożek napływowy; 15 dolina plejstoceńska; 16 - dolina holoceńska; 17 - krawędź plejstoceńska $(<5 \mathrm{~m}) ; 18$ - krawędź plejstoceńska $(>5 \mathrm{~m}) ; 19$ niewyraźna krawędź (załom) plejstoceńska; 20 - krawędź holoceńska ( $<5 \mathrm{~m}) ; 21$ - krawędź holoceńska ( $>5 \mathrm{~m}) ; 22$ - niewyraźna krawędź (załom) holoceńska; 23 - linijne rozcięcie erozyjne; 24 - sztuczne koryto i rów melioracyjny; 25 - krawędź antropogeniczna (<1 m); 26 - niewyraźna (zatarta) krawędź antropogeniczna; 27 - antropogeniczne rozcięcie erozyjne; 28 kopalnia, wyrobisko, antropogeniczna depresja jeziorna; 29 - hałda, nasyp; 30 - badane profile geologiczne PK 1 i PK 2

Geomorphological map of the Kamionka River Valley downstream of Suchedniów (by P. Przepióra)

1 - gentle slope $\left(2-6^{\circ}\right) ; 2$ - steep slope (above $\left.6^{\circ}\right) ; 3$ - kame terrace; 4 - higher (5-12 m a.r.1.) fluvial terrace, Wartanian stadial; 5 - lower (3-4 m a.r.1.) fluvial terrace, Vistula glaciation; 6 - dune; 7 - higher (2-2.5 m a.r.l.) floodplain, Holocene; 8 - lower (1-1.5 m a.r.l.) floodplain, Holocene; 9 - main alluvial riverbed; 10 - secondary alluvial riverbed; 11 - Holocene palaeomeander; 12 - dam and weir on the river; 13 - levee; 14 - alluvial fan; 15 - Pleistocene valley; 16 - Holocene valley; 17 - Pleistocene edge ( $<5 \mathrm{~m}) ; 18$ - Pleistocene edge (> $5 \mathrm{~m}) ; 19$ - indistinct Pleistocene edge; 20 - Holocene edge $(<5 \mathrm{~m})$; 21 - Holocene edge ( $>5 \mathrm{~m}$ ); 22 - Holocene blurred edge (bend); 23 - linear erosion cut; 24 - artificial riverbed and drainage channel; 25 - anthropogenic edge ( $<1 \mathrm{~m}) ; 26$ - indistinct anthropogenic edge; 27 - anthropogenic erosion cut; 28 - mine, pit, artificial pond depression; 29 - mound, embankment; 30 - study geological profiles PK 1 and PK 2 


\section{Obszar badań}

Kamionka, prawy dopływ Kamiennej, jest niewielką wyżynną, meandrującą rzeką na Płaskowyżu Suchedniowskim (Kondracki 2002). Jej długość wynosi około $17 \mathrm{~km}$, a średni spadek około 5\%. Zlewnia o powierzchni $107 \mathrm{~km}^{2}$ w SE części położona jest na trzonie paleozoicznym Gór Świętokrzyskich, natomiast pozostała część leży w obrębie mezozoicznego obrzeżenia tych gór. Przebieg głównej doliny i układ sieci rzecznej w zlewni uwarunkowany jest kierunkiem spękań ciosowych (Kosmowska-Suffczyńska 2000) i ruchami neotektonicznymi (Kowalski 2002b).

W dolnym i górnym odcinku Kamionka sformowała przełomy pomiędzy wzgórzami zbudowanymi $\mathrm{z}$ piaskowca triasowego, natomiast $\mathrm{w}$ środkowym występuje rozszerzenie, w którym rzeka swobodnie meandruje i wcina się w osady fluwioglacjalne zlodowacenia odry, tworząc szereg teras (Krajewski 1955; Filonowicz 1962a, b, 1971a, b, 1978a, b; Lewandowski i in. 1975; Przepióra 2017).

Zlewnia leży w granicach Staropolskiego oraz Centralnego Okręgu Przemysłowego, co spowodowało silne antropogeniczne przemodelowanie doliny oraz samej rzeki (50\% jej długości) na potrzeby rozwijającego się tu prężnie od XVII w. przemysłu opartego na wydobyciu i przetwarzaniu rudy żelaza (Przepióra 2017).

Analizowane profile znajdują się na odcinku poniżej Suchedniowa, gdzie ingerencja człowieka oraz przekształcenia rzeźby były stosunkowo niewielkie, a naturalne formy są dobrze czytelne. Zlokalizowano je na terasie wyższej (5-12 m), zachowanej na całym odcinku wzdłuż prawego zbocza doliny w formie listwy o zmiennej szerokości od $400 \mathrm{~m}$ w Suchedniowie (PK 2) do $50 \mathrm{~m}$ w przełomie (PK 1) (rys. 2). Można ją korelować z terasą środkowopolską G III Lewandowskiego i in. (1975) zachowaną na tym odcinku pod lewym zboczem doliny.

\section{Wyniki badań}

Profil PK 2 położony jest na obszarze nieczynnej piaskowni około $400 \mathrm{~m}$ na $\mathrm{N}$ od centrum Suchedniowa i $200 \mathrm{~m}$ na SE od oczyszczalni ścieków. Profil został wykonany na ścianie dawnego wyrobiska, która podcina terasę na odcinku kilkuset metrów.
W 4-metrowym odsłonięciu można wyróżnić 3 zespoły litofacjalne (rys. 3). Dolny o miąższości 3,3 m budują osady piaszczyste, poziomo warstwowane (Sh), niekiedy z drobnymi ripplemarkami (Sr). W górnych $70 \mathrm{~cm}$ występuje struktura masywna $(\mathrm{Sm})$, co może być związane $\mathrm{z}$ pierwotnym warstwowaniem, które zostało zniszczone przez procesy glebotwórcze w czasie rozwoju nadległej gleby kopalnej (Bs - poziom iluwialno-żelazisty tej gleby). Na cały zespół składa się kilkadziesiąt warstw o różnej miąższości. W większości przeważają piaski średnioziarniste ze znacznym udziałem piasków drobnoziarnistych (Mz około 1,5 phi) i sporadycznie pojawiającą się domieszką pojedynczych drobnych żwirów $(\mathrm{S}(\mathrm{G}) \mathrm{h})$. Są to osady dobrze wysortowane $\left(\delta_{\mathrm{I}}\right.$ około $0,5)$. W całym zespole występuje tylko kilka cienkich, kilkucentymetrowych przewarstwień osadów z domieszką drobnych frakcji (maks. do kilku \%) (S(F)h), co powoduje tylko nieznaczne pogorszenie wysortowania oraz zaznacza się w skośności i kurtozie osadów. Na głębokości $3 \mathrm{~m}$ występuje charakterystyczna jasnowiśniowa lamina, będąca barierą geochemiczną w migracji żelaza. Zbudowana jest $\mathrm{z}$ zabarwionego na ten kolor średnioziarnistego piasku oraz pojedynczych żwirów (do $2 \mathrm{~cm}$ średnicy) wiśniowego piaskowca triasowego, którego wychodnie znajdują się w górnym biegu rzeki $(\mathrm{S}(\mathrm{G}) \mathrm{h})$. Układ warstw wskazuje na występowanie w profilu raz grubszych, raz drobniejszych osadów, bez dającej się zauważyć regularności lub prawidłowości. Zespół litofacjalny może być interpretowany litogenetycznie jako płytkie, niskoenergetyczne subśrodowisko sedymentacyjne piaszczystego, górnego, płaskiego dna (SU), a datowania TL wskazują, że był akumulowany w stosunkowo krótkim okresie, gdyż jego wiek w dolnej, środkowej i górnej części wynosi odpowiednio $124,3 \pm 18,6 \quad$ ka (KIE-844), $122,8 \pm 18,4$ ka (KIE-843), 122,5 $\pm 18,4$ ka (KIE842) (Przepióra i in. 2014).

Środkowy zespół litofacjalny, o miąższości około $40 \mathrm{~cm}$ tworzy bardzo dobrze wykształcona kopalna gleba bielicowa $(\mathrm{Cm}), \mathrm{z}$ poziomem próchnicznym (A) i poziomem bielicowania (Es). Poziom B tej gleby wykształcił się już W górnej części poprzednio opisanego zespołu litofacjalnego. Bielica rozwinęła się na piaskach drobnych i średnich (Mz około 2,0 phi), dobrze wysortowanych $\left(\delta_{\mathrm{I}}\right.$ około 0,5$), \mathrm{z}$ niewielkim udziałem frakcji pylasto-ilastych $(\mathrm{S}(\mathrm{F}) \mathrm{m})$ będących efektem procesów glebotwórczych. 


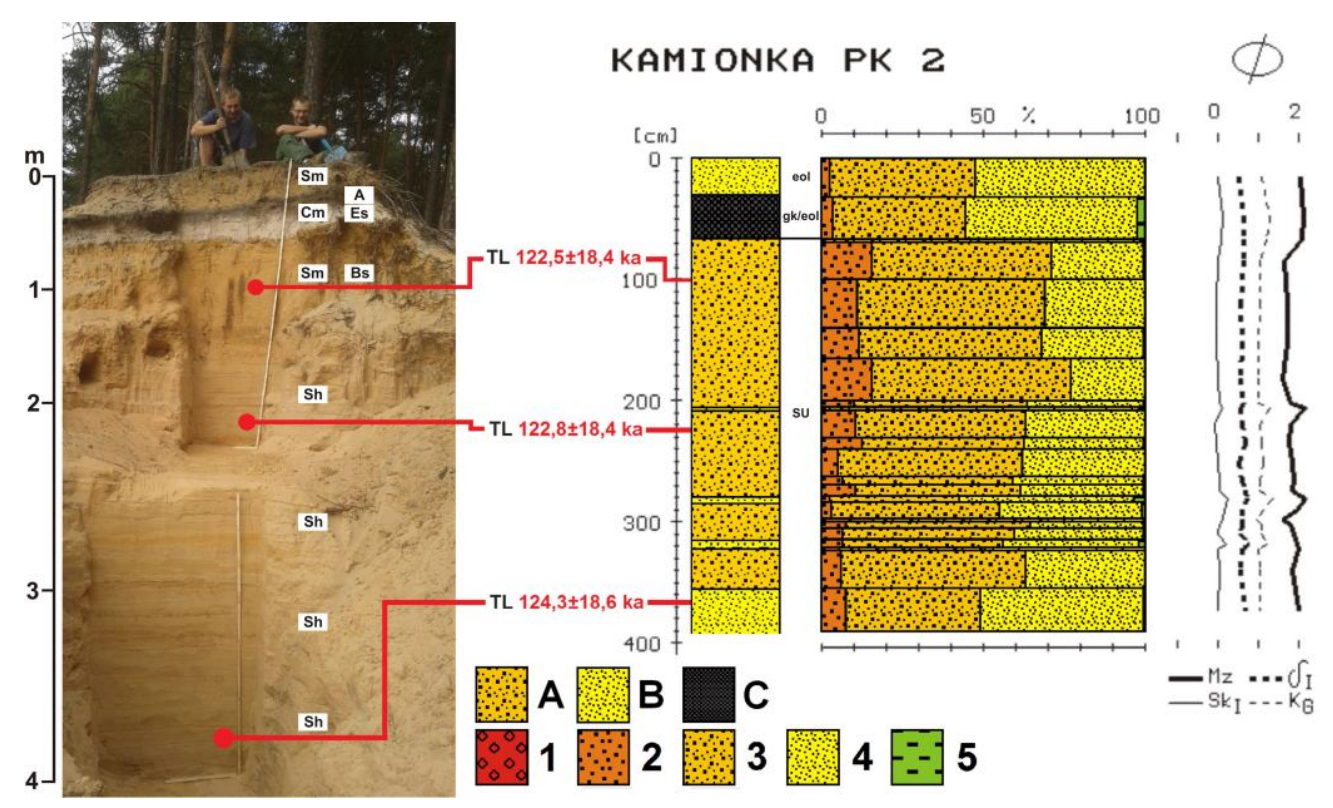

Rys. 3. Profil PK 2: litologia, granulometria, wskaźniki uziarnienia Folka-Warda i datowania TL

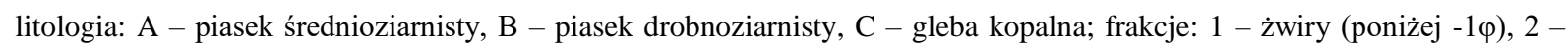
piaski gruboziarniste $(-1-1 \varphi), 3$ - piaski średnioziarniste $(1-2 \varphi), 4$ - piaski drobnoziarniste $(2-4 \varphi), 5$ - pyły i iły (powyżej $4 \varphi$ ); wskaźniki uziarnienia Folka-Warda: $\mathrm{Mz}$ - średnia średnica, $\delta_{\mathrm{I}}$ - odchylenie standardowe, Sk - skośność, $\mathrm{K}_{\mathrm{G}}-$ kurtoza; objaśnienia kodów litofacjalnych (Sm, Cm, Sh), litogenetycznych (SU) i poziomów glebowych (A, Es, Bs) w tekście; eol osady eoliczne, gk - gleba kopalna

PK 2 profile: lithology, grain size, Folk-Ward distribution parameters and TL datings

lithology: A - medium sand; B - fine sand, C - buried soil; fractions: 1 - gravels (below $-1 \varphi)$; 2 - coarse sands $(-1-1 \varphi), 3-$ medium sands $(1-2 \varphi), 4$ - fine sands $(2-4 \varphi), 5$ - silts and clays (above $4 \varphi$ ); Folk-Ward's distribution parameters: Mz - mean size, $\delta_{\mathrm{I}}$ - standard deviation, $\mathrm{Sk}_{\mathrm{I}}$ - skewness, $\mathrm{K}_{\mathrm{G}}$ - kurtosis; explanations of the lithofacial codes $(\mathrm{Sm}, \mathrm{Cm}, \mathrm{Sh})$, lithogenetic codes (SU) and soil horizons (A, Es, Bs) in the text; eol - aeolian deposits, gk - buried soil

Cały profil zamyka, złożony na glebie kopalnej, trzeci zespół o miąższości około $30 \mathrm{~cm}$, który budują piaski drobne i średnie (Sm), bardzo zbliżone uziarnieniem i wskaźnikami Folka-Warda do osadów, na których wytworzyła się gleba kopalna.

Profil PK 1 zlokalizowano na początku dolnego przełomu Kamionki (rys. 2). Dolina zwęża się tu do około $300 \mathrm{~m}$. Zachowana na prawym brzegu listwa terasy o szerokości około $150 \mathrm{~m}$ jest silnie rozczłonkowana holoceńskimi dolinkami erozyjnymi u wylotu starszych, plejstoceńskich form fluwialno-denudacyjnych wyciętych w zboczu doliny. Profil został ulokowany na ostańcu terasy ograniczonym rynnami erozyjnymi, ma głębokość $5 \mathrm{~m}$ i można w nim wydzielić kilka zespołów litofacjalnych (rys. 4).

Dolny kompleks litofacjalny, o miąższości 4,2 m, budują warstwy piaszczysto-żwirowe (SG). Są to piaski średnioziarniste ze znacznym udziałem drobnoziarnistych $(\mathrm{Mz}=1,5-2,0$ phi) i kilkuprocentową domieszką żwirów, dochodzącą w niektórych przypadkach (poziom rozmycia na głębokości 2,0 m) do 5\%, co powoduje spadek średniej średnicy do poniżej 0,5 phi. Osady są dobrze wysortowane $\left(\delta_{\text {I }}\right.$ około 0,5$)$. W całym kompleksie zaznaczają się dwie fazy agradacji $\mathrm{z}$ niewyraźną tendencją drobnienia osadów ku górze. W pierwszej fazie akumulowane były piaski rynnowo (St) i przekątnie warstwowane (Sx) (głębokość poniżej 3,5 m), a w profilu widoczne są liczne płytkie rozmycia kanałowe wypełnione piaskami przekątnie warstwowanymi (Ss) (rys. 5). Ten zespół litofacjalny może być interpretowany litogenetycznie jako piaszczyste formy dna (SB) (megariplemarki MR i riplemarki RM) z wypełnieniami rozmyć (struktur kanałowych SP). Osady były akumulowane w piaskodennym korycie rzecznym o znacznej energii środowiska fluwialnego, jak wskazuje datowanie TL, około $127,1 \pm 19,1 \mathrm{ka}$ (KIE-841). W drugiej fazie agradacji akumulowane były piaski poziomo warstwowane (Sh) (głębokość 3,5-0,8 m). W interpretacji litogenetycznej można przyjąć, że ten zespół litofacjalny reprezentuje płytkie subśrodowisko sedymentacyjne piaszczystego, górnego, płaskiego dna (SU), prawdopodobnie w brzeżnej części równiny aluwialnej. Datowania TL $119,6 \pm 18,0$ ka (KIE-840) i 119,9 $\pm 18,0$ ka (KIE- 
839) wskazują, że akumulacja zachodziła w stosunkowo krótkim okresie.

Powyżej występuje warstwa diamiktonu ostrokrawędzistych okruchów piaskowca triasowego wielkości do 10-15 cm zalegających w piaskach (Mz=-0,7 phi)(BD) (rys. 6). Źle wysortowane $\left(\delta_{\mathrm{I}}=1,6\right)$ osady tej litofacji mają miąższość $10-20 \mathrm{~cm}$. Piaskowce triasowe budują na tym odcinku prawe zbocze doliny, do którego przylega terasa.

Górny zespół litofacjalny, o miąższości około $60 \mathrm{~cm}$, tworzą osady piaszczyste ( $\mathrm{Mz}$ około 1,5 phi), które są dobrze wysortowane $\left(\delta_{\mathrm{I}}\right.$ około
$0,5)$ i mają strukturę masywną $(\mathrm{Sm})$. Datowanie TL wskazuje, że ich wiek należy szacować na $>96,0$ ka (KIE-838). Niewykluczone, że pierwotne struktury $\mathrm{w}$ tej litofacji zostały zatarte przez procesy glebotwórcze, gdyż $\mathrm{w}$ stropie profilu wykształcona jest współczesna gleba $(\mathrm{Cm})$, z poziomem organicznym $(\mathrm{O})$ o miąższości około $15 \mathrm{~cm}$. Brak w profilu głębszych poziomów bielicy wskazuje na erozyjne ogłowienie starszej gleby i ponowne wykształcenie bardzo młodego poziomu organicznego, który tworzy inicjalne stadium bielicy.

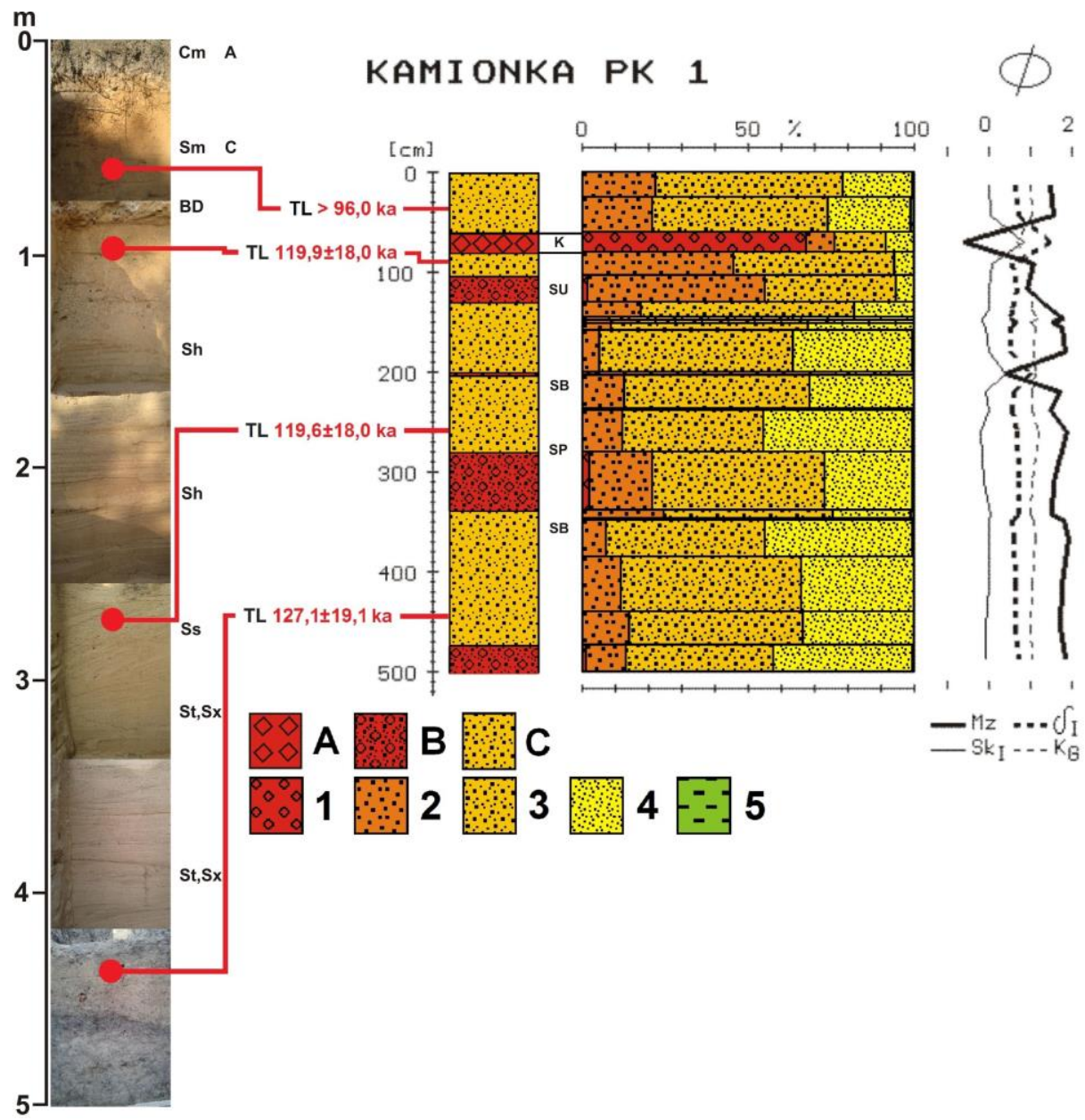

Rys. 4. Profil PK 1: litologia, granulometria, wskaźniki uziarnienia Folka-Warda i datowania TL

litologia: A - rumosz skalny, B - piasek ze żwirem, C - piasek różnoziarnisty; frakcje: 1 - żwiry (poniżej $-1 \varphi$ ), $2-$ piaski gruboziarniste $(-1-1 \varphi), 3$ - piaski średnioziarniste $(1-2 \varphi), 4$ - piaski drobnoziarniste $(2-4 \varphi), 5$ - pyły i iły (powyżej $4 \varphi)$; wskaźniki uziarnienia Folka-Warda: Mz - średnia średnica, $\delta_{\mathrm{I}}$ - odchylenie standardowe, SkI - skośność, KG - kurtoza; objaśnienia kodów litofacjalnych $(\mathrm{Sx}, \mathrm{St}, \mathrm{Ss}, \mathrm{Sh}, \mathrm{BD}, \mathrm{Sm}, \mathrm{Cm})$, litogenetycznych (SU, SB, SP) i poziomów glebowych (A, C) w tekście; K - koluwia

PK 1 profile: lithology, grain size, Folk-Ward distribution parameters and TL datings

lithology: A - rock fragment; B - sand and gravel, C - coarse sand; fractions: 1 - gravels (below -1 $\varphi$ ); 2 - coarse sands $(-1-1 \varphi), 3$ - medium sands $(1-2 \varphi), 4$ - fine sands $(2-4 \varphi), 5$ - silts and clays (above $4 \varphi)$; Folk-Ward's distribution parameters: $\mathrm{Mz}$ - mean size, $\delta_{\mathrm{I}}$ - standard deviation, $\mathrm{SkI}$ - skewness, $\mathrm{K}_{\mathrm{G}}$ - kurtosis; explanations of the lithofacial codes (Sx, St, Ss, Sh, BD, Sm, Cm), lithogenetic codes (SU, SB, SP) and soil horizons (A, C) in the text; K - colluvium 


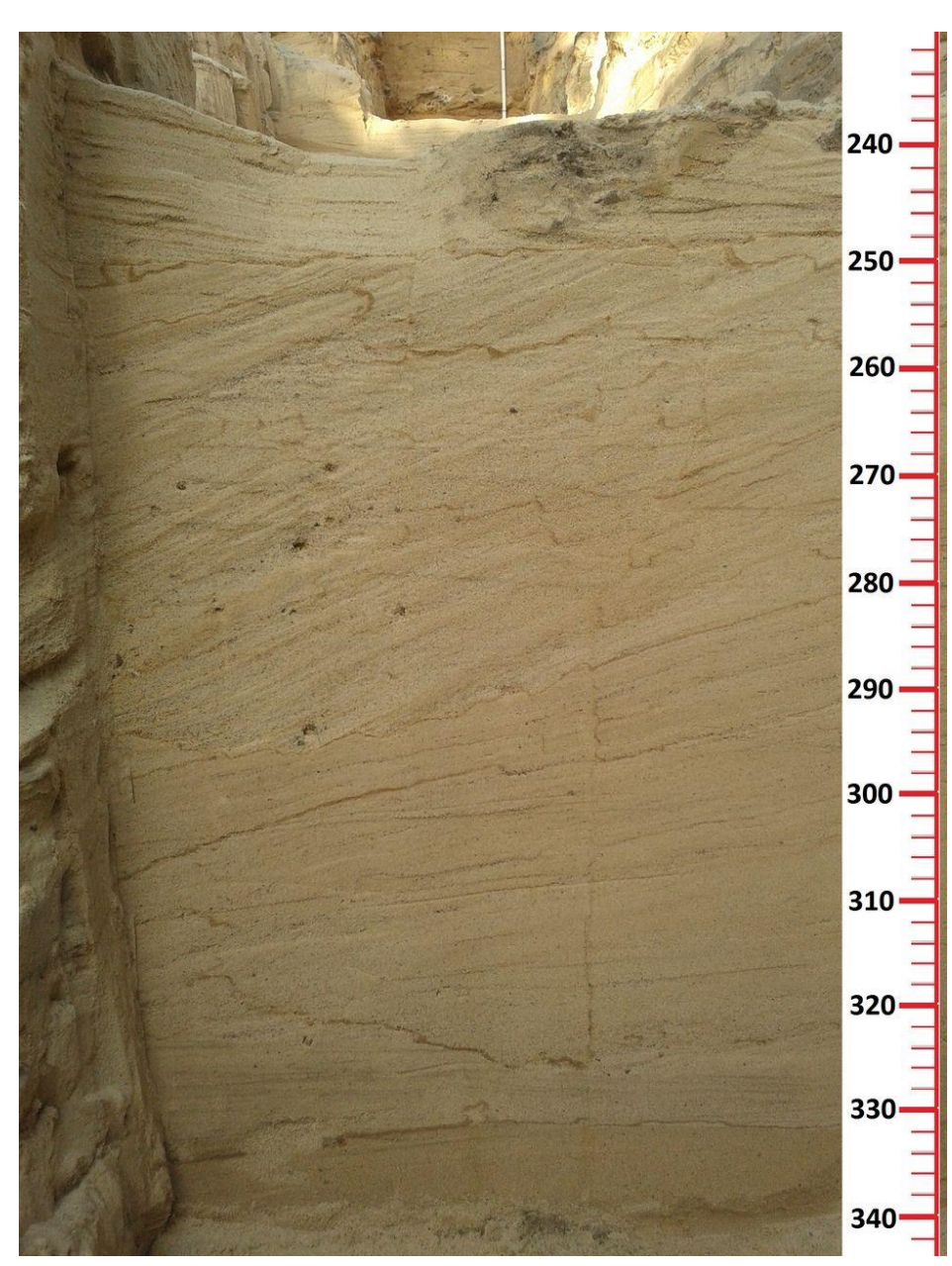

Rys. 5. Przekątnie i rynnowo warstwowane osady korytowe w dolnej części profilu PK 1

Cross-bedded channel sediments in the lower part of the PK 1 profile

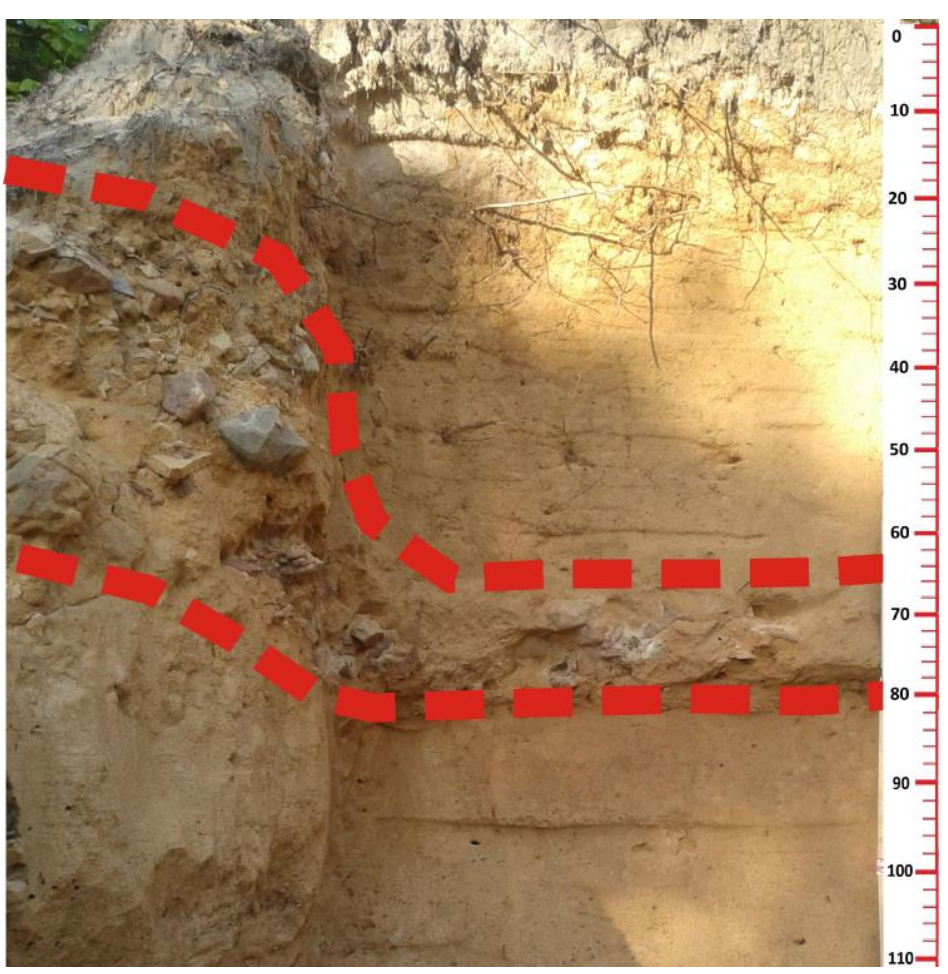

Rys. 6. Warstwa gruboklastycznych osadów (proluwiów) w górnej części profilu PK 1

A layer of very coarse colluvium in the upper part of the PK 1 profile 


\section{Dyskusja}

Wyniki badań potwierdziły środkowopolski wiek wyższej terasy Kamionki, co sugerował Lewandowski i in. (1975). Prawobrzeżna terasa odpowiadałaby terasie G III wydzielanej przez tych autorów w lewobrzeżnej części doliny Kamionki i jej lewego dopływu Łosiennicy.

Terasa wyższa jest terasą akumulacyjną, której aluwia narastały w okresie kataglacjalnym stadium warty, na co wskazują datowania TL (127-119 ka). Osady deponowane były na równinie aluwialnej piaszczystodennej rzeki roztokowej w kilku różnowiekowych etapach (co mogłyby sugerować datowania TL w profilu PK 1) i w różnych subśrodowiskach sedymentacyjnych - korytowym (piaszczysto-żwirowe aluwia korytowe, rynnowo warstwowane w PK 1) oraz płytkiego, górnego, płaskiego dna (piaski poziomo warstwowane w PK 1 i PK 2).

Tekstura i struktura aluwiów odzwierciedla też lokalną sytuację geomorfologiczną i dynamikę przepływów (por. Huisink 1998; Forysiak 2005, 2010; Zieliński 1998, 2014). W rozszerzeniu (profil PK 2), gdzie rzeka roztokowa tworzyła rozległą równinę aluwialną, w brzeżnych częściach dna doliny występowały przez długi okres liczne drugorzędne nurty, w których gromadziły się poziomo warstwowane, dobrze wysortowane piaski średnioziarniste $\mathrm{z}$ przewarstwieniami drobnoziarnistego żwiru i gruboziarnistego piasku. Zmienność subśrodowisk sedymentacyjnych musiała być $w$ tych odcinkach stosunkowo niewielka, gdyż miąższości akumulowanych w nich zespołów litofacjalnych dochodzą do $3 \mathrm{~m}$, natomiast w przełomie (profil PK 1) równina aluwialna była węższa, a ilość koryt drugorzędnych zredukowana. W sedymentacji większą rolę odgrywała depozycja grubszych aluwiów, przekątnie i rynnowo warstwowanych, w wysokoenergetycznym subśrodowisku głównego nurtu. Jego boczna migracja powodowała zmienność subśrodowisk sedymentacyjnych i związaną z tym mniejszą miąższość zespołów litofacjalnych. Dlatego w profilu PK 1 litofacje reprezentujące formy denne (SB) zostały zastąpione przez litofacje górnego płaskiego dna (SU) o miąższości nieprzekraczającej $1,5 \mathrm{~m}$.

Wyniki badań potwierdziły również poligenetyczność osadów występujących na terasach środkowopolskich i ich nadbudowanie przez pokrywy gruzowe, na co zwracali uwage Klatkowa (1955) i Klatka (1956). Autorzy ci wiązali to $\mathrm{z}$ pokrywami soliflukcyjnymi $\mathrm{z}$ okresu vistu- lianu. W przypadku terasy Kamionki (profil PK 1) takie nałożenie gruboklastycznych osadów stokowych (ostrokrawędziste okruchy piaskowca) na aluwia również miało miejsce w odcinku przełomowym, gdzie terasa przylega bezpośrednio do stromych zboczy. Wydaje się jednak, że nie są to osady jęzora soliflukcyjnego, lecz proluwia złożone u wylotu jednej z krótkich dolinek rozcinających zbocza przełomu. Na tym odcinku rzeka nie posiadała wystarczającej siły do transportu tak grubej frakcji i warstwę przykryła kolejna litofacja aluwiów. Również depozycja proluwiów miała miejsce prawdopodobnie w okresie kataglacjalnym, choć nie jest wykluczony również wczesnovistuliański wiek tych osadów (datowanie TL starsze niż $96 \mathrm{ka}$ ). Za pierwszą interpretacją przemawia wzrost intensywności transportu poprzecznego do osi doliny, notowany u schyłku glacjałów, kiedy gruboklastyczna zwietrzelina peryglacjalna niepokryta roślinnością mogła być łatwo uruchamiana przez procesy morfogenetyczne na stokach i dostarczana do głównych dolin przez boczne dopływy.

W obu profilach aluwia kończy facja zamierającego koryta (por. Zieliński 2014), co świadczy o spadku aktywności roztokowej Kamionki na równinie aluwialnej i prawdopodobnie bezpośrednio poprzedza fazę jej rozcięcia. Nastąpiło to przypuszczalnie u schyłku stadiału warty i w eemie, co potwierdza schemat faz erozji i akumulacji w klimatycznym cyklu interglacjalno-glacjalnym (por. Zieliński 2014, tam literatura).

W vistulianie następowała akumulacja aluwiów niższej terasy Kamionki, która najprawdopodobniej została rozcięta $\mathrm{w}$ późnym glacjale, kiedy rzeka zmieniła rozwinięcie $\mathrm{z}$ roztokowego na meandrowe. Wielkie paleomeandry $\mathrm{z}$ tego okresu zachowały się $\mathrm{w}$ poziomie równiny zalewowej (Przepióra 2017), co jest zgodne ze schematem ewolucji dolin środkowoeuropejskich w tym okresie (por. Kalicki 2006, tam literatura). $\mathrm{W}$ młodszym pleniglacjale lub późnym glacjale zwydmieniu uległa także powierzchnia wyższej terasy, czego ślady, w postaci niewielkich wydm, odnajdujemy dziś w sąsiedztwie cmentarza miejskiego w Suchedniowie. Działalność eoliczną dokumentują też dwa górne zespoły litofacjalne w profilu PK 2. Niższy z nich, na którym wykształciła się holoceńska bielica, powstał zapewne jeszcze u schyłku plejstocenu, natomiast młodszy odzwierciedla antropogeniczne ożywienie procesów wydmotwórczych po odlesieniu obszaru w ostatnich stuleciach, co potwierdzają diagram pyłkowy (Szczepanek 1961) i dane historyczne (Przepióra 2017). 


\section{Wnioski}

Terasę wyższą (5-12 m) Kamionki pomiędzy Suchedniowem i Rejowem budują piaszczysto-żwirowe aluwia korytowe, poziomo, przekątnie i rynnowo warstwowane, składane przez rzekę roztokową $\mathrm{w}$ okresie kataglacjalnym stadiału warty (datowania TL: 127-119 ka). Ich uziarnienie i struktura są różne $\mathrm{w}$ rozszerzeniach i zwężeniach doliny, co uwarunkowane było zmienną energią przepływów i zróżnicowaniem subśrodowisk sedymentacji fluwialnej. W przełomowym odcinku doliny aluwia zostały przykryte przez bardzo gruboklastyczne osady proluwialne. Powierzchnia terasy uległa zwydmieniu w vistulianie pod wpływem czynnika klimatycznego i ponownie w ostatnich stuleciach wskutek czynników antropogenicznych.

\section{Literatura}

Bartosik J. 1972. Geomorfologia obrzeżenia Gór Świętokrzyskich w okolicach Iłży. Acta Geographica Lodziensia 29: 1-87.

Ber A., Lindner L., Marks L. 2007. Propozycja podziału stratygraficznego czwartorzędu Polski. Przegląd Geologiczny 55: 115-118.

Czarnik J. 1966. Stratygrafia czwartorzędu północnych okolic Koniecpola nad Pilicą. Acta Geologica Polonica 16(3): 379-400.

Czarnocki J. 1927. O zlodowaceniach środkowej części Gór Świętokrzyskich. Posiedzenia Naukowe PIG 17: 18-21.

Czarnocki J. 1931. Dyluwium Gór Świętokrzyskich. Rocznik PTG 7: 82-104.

Filonowicz P. 1962a. Objaśnienia do Szczegółowej mapy geologicznej Polski 1:50 000, ark. Bodzentyn. Wyd. Geol., Warszawa: 1-85.

Filonowicz P. 1962b. Szczegółowa mapa geologiczna Polski w skali 1:50 000, ark. Bodzentyn. Wyd. Geol., Warszawa.

Filonowicz P. 1971a. Objaśnienia do Szczegółowej mapy geologicznej Polski 1:50 000, ark. Kielce. Wyd. Geol., Warszawa: 1-71.

Filonowicz P. 1971b. Szczegółowa mapa geologiczna Polski w skali 1:50 000, ark. Kielce. Wyd. Geol., Warszawa.

Filonowicz P. 1978a. Objaśnienia do Szczegółowej mapy geologicznej Polski 1:50 000, ark. Skarżysko-Kamienna. Wyd. Geol., Warszawa: $1-71$.

Filonowicz P. 1978b. Szczegółowa mapa geologiczna Polski w skali 1:50 000, ark. SkarżyskoKamienna. Wyd. Geol., Warszawa.

Folk R.L., Ward W.C. 1957. Brazos River bar: A study in the significance of grain size pa- rameters. Journal of Sedimentary Petrology 27: 3-26.

Forysiak J. 2005. Rozwój doliny Warty między Burzeninem i Dobrowem po zlodowaceniu warty. Acta Geographica Lodziensia 90: 1-116.

Forysiak J. 2010. Zastosowanie analizy zdjęć lotniczych do rekonstrukcji układu wielokorytowego środkowej Warty. Landform Analysis 13: 13-18.

Gilewska S. 1972. Wyżyny Śląsko-Małopolskie. W: M. Klimaszewski (red.) Geomorfologia Polski. PWN, Warszawa: 234-340.

Hakenberg M., Lindner L. 1971. Stratygrafia osadów czwartorzędowych w dolinie środkowej Nidy. Acta Geologica Polonica 21(2): 241-264.

Hakenberg M., Lindner L. 1973. Holoceński rozwój doliny środkowej Nidy. Acta Geologica Polonica 23(2): 435-444.

Huisink M. 1998. Changing river styles in response to climate change: examples from the Maas and Vecht during the Weichselian Pleniglacial and Lateglacial. PhD Thesis. Vrije Universiteit, Faculty of Earth Sciences (Amsterdam): 1-127.

Jaśkowski B. 1996. Geneza i wiek wydm Gór Świętokrzyskich w świetle datowań ${ }^{14} \mathrm{C}$ i TL. Zeszyty Naukowe Politechniki Ślaskiej, Seria: Mat.Fiz.: Geochronometria 14, 1331: 31-46.

Kalicki T. 2006. Zapis zmian klimatu oraz działalności człowieka i ich rola w holoceńskiej ewolucji dolin środkowoeuropejskich. Prace Geograficzne IGiPZ PAN 204: 1-349.

Kalicki T., Krupa J., Przepióra P., Kłusakiewicz E., Kusztal P., Frączek M., Górska-Zabielska M., Nowak M., Pawłowski D., Petr L., Przeździecki M., Przychodni A. 2016. River valley evolution of Holy Cross Mountains region. Field Guide of_FLAG Biennial Meeting "Evolution of river valleys in Central Europe", Kielce-Suchedniów: 48-93.

Klatka T. 1955. Suche doliny płaskodenne na przedpolu Łysogór. Biuletyn Peryglacjalny 2: 7989.

Klatka T. 1962. Geneza i wiek gołoborzy łysogórskich. Acta Geographica Lodziensia 12: 1-124.

Klatka T. 1964. Geomorfologia Gór Świętokrzyskich. Roczniki Gleboznawcze XV (dod.): 129-154.

Klatka T. 1968. Holoceńskie procesy rzeźbotwórcze w obszarze Gór Świętokrzyskich. Folia Quaternaria 29: 89-95.

Klatkowa H. 1955. Utwory stokowe na terasie Kamiennej pod Wąchockiem. Biuletyn Peryglacjalny 2: 91-99.

Klimaszewski M. 1952. Zagadnienia plejstocenu południowej Polski. Biuletyn Państwowego Instytutu Geologicznego 65: 137-268.

Kondracki J. 2002. Geografia regionalna Polski. PWN, Warszawa. 
Kosmowska-Suffczyńska D. 1966. Rozwój rzeźby w trzeciorzędzie okolic Ostrowca Świętokrzyskiego i Ćmielowa. Prace Geograficzne IGiPZ PAN 54: 1-114.

Kosmowska-Suffczyńska D. 2000. Wpływ drobnych struktur tektoniki dysjunktywnej na kierunkowość rzeźby w północno-wschodnim obrzeżeniu Gór Świętokrzyskich. Geologia i geomorfologia Gór Świętokrzyskich - kontrowersje i nowe spojrzenia. Prace Instytutu Geografii WSP, Kielce: 171-208.

Kowalski B. 1988. Rozwój rzeźby przełomowego odcinka doliny rzeki Lubrzanki przez główne pasmo Gór Świętokrzyskich w czwartorzędzie. Przeglad Geograficzny LX,4: 635-653.

Kowalski B. 2002a. Geneza i wiek osadów terasy zalewowej i nadzalewowej (wysokiej) środkowego odcinka doliny Lubrzanki w Górach Świętokrzyskich. Prace Instytutu Geografii Akad. Świętokrzyskiej 8: 151-216.

Kowalski B. 2002b. Geneza układu sieci rzecznej w Górach Świętokrzyskich. Prace Instytutu Geografii Akad. Świętokrzyskiej 7: 315-51.

Krajewski R. 1955. Szczegółowa mapa geologiczna Polski w skali 1:50 000, ark. Odrowąż. Wyd. Geol., Warszawa.

Krupa J. 2013. Naturalne i antropologiczne procesy kształtujące dno doliny Czarnej Nidy w późnym vistulianie i holocenie. Folia Quaternaria 81: 5-156.

Krupa J. 2015. Natural and anthropogenic channel pattern changes in the mid-mountain valley during the Late Glacial and Holocene, Polish Uplands. Quaternary International 370: 5565.

Lamparski Z. 1970. Dynamika ruchu brzeżnej części lądolodu w czasie transgresji zlodowacenia środkowopolskiego na północno-wschodnie zbocza Gór Świętokrzyskich. Acta Geologica Polonica 20: 587-602.

Lencewicz S. 1913. Dzieje górnej Lubrzanki (Czarnej Nidy) w czwartorzędzie. Pamiętnik Fizjograficzny 21. Dz. II.

Lencewicz S. 1934. Le massif hercynien des Łysogóry (Ste Croix) et ses envelopes. Congres Intern. De Geogr. Varsovie.

Lewandowski J., Romanek A., Studencki M. 1975. Formy akumulacji międzylobowej w rejonie Suchedniowa. Kwartalnik Geologiczny 19,4: 887-906.

Lindner L. 1970. Czwartorzęd północno-zachodniego obrzeżenia Gór Świętokrzyskich. Acta Geologica Polonica XX(3): 636-645.

Lindner L. 1971. Stratygrafia plejstocenu i paleogeomorfologia północno-zachodniego obrzeżenia Gór Świętokrzyskich. Studia Geologica Polonica 35: 1-113.

Lindner L. 1979. Rozwój paleogeomorfologiczny zachodniej części regionu świętokrzyskiego w plejstocenie. Roczniki Polskiego Towarzystwa Geologicznego 48,3-4: 479-508.

Lindner L. 1980. Zarys chronostratygrafii czwartorzędu regionu świętokrzyskiego. Kwartalnik Geologiczny 24,3: 689-716.

Lindner L. 1984a. Region świętokrzyski: Zlodowacenie środkowopolskie. Interglacjał eemski. Zlodowacenie północnopolskie. W: J.E. Mojski (red.) Budowa geologiczna Polski, t. I, cz. 3bczwartorzęd. Wyd. Geol., Warszawa: 255-286.

Lindner L. 1984b. Holocen: Region świętokrzyski. W: J.E. Mojski (red.) Budowa geologiczna Polski, t. I, cz. 3b - czwartorzęd. Wyd. Geol., Warszawa: 326-330.

Lindner L. 1988. Jednostki glacjalne i interglacjalne w plejstocenie regionu świętokrzyskiego. Przeglad Geologiczny 41,7: 31-39.

Lindner L. 2004. Zarys stratygrafii plejstocenu Regionu Świętokrzyskiego. Prace Instytutu Geografii Akad. Świętokrzyskiej 13, Kielce: 7-32.

Lindner L. 2005. Nowe spojrzenie na liczbę, wiek i zasięgi zlodowaceń środkowopolskich w południowej części środkowowschodniej Polski. Przeglad Geologiczny 53(2): 145-150.

Lindner L., Marks L. 2012. O podziale klimatostratygraficznym kompleksu środkowopolskiego w plejstocenie Polski. Przegląd Geologiczny 60(1): 36-45.

Ludwikowska-Kędzia M. 2005. Litostratygrafia plejstoceńskich teras nadzalewowych dolin rzek Belnianki i Łagowicy w Górach Świętokrzyskich. VII Zjazd Geomorfologów Polskich „Współczesna ewolucja rzeźby Polski”, 1922.09.2005 Kraków: 265-270.

Łyczewska J. 1959. Czwartorzęd regionu świętokrzyskiego w świetle aktualnej problematyki. Przegląd Geologiczny 1: 86-91.

Łyczewska J. 1971. Czwartorzęd regionu świętokrzyskiego. Stratygrafia kenozoiku Gór Świętokrzyskich i ich obrzeżenia. Prace Instytutu Geologicznego LXIV: 5-86.

Mojski J.E. 1993. Europa w plejstocenie. Wyd. PAE, Warszawa.

Mojski J.E. 2005. Ziemie polskie w czwartorzędzie. PIG, Warszawa.

Mycielska-Dowgiałło E. 1969. Próba rekonstrukcji warunków paleohydrodynamicznych rzeki na podstawie badań sedymentologicznych w dolinie Wisły pod Tarnobrzegiem. Przegląd Geograficzny 44,3: 409-429.

Mycielska-Dowgiałło E. 1972. Rozwój doliny środkowej Wisły w holocenie w świetle badań okolic Tarnobrzega. Przegląd Geograficzny 44,1: 73-83.

Nowak M.M. 2017. Budowa geologiczna i rzeźba doliny Czarnej Koneckiej w rejonie Wąsosza Starej Wsi. Maszynopis pracy magisterskiej. Archiwum UJK, Kielce.

Przepióra P. 2017. Naturalne i historyczne zmiany zlewni Kamionki (Płaskowyż Suchedniowski) 
w subatlantyku. Maszynopis pracy doktorskiej. Archiwum UJK, Kielce.

Przepióra P., Kalicki T., Podrzycki Ł. 2014. Structure and origin of Kamionka river terrace in Suchedniów - first results. Sbornik abstrakt 20. Kvarter, Ustav geologickych ved $\operatorname{PrF} \mathrm{MU}$, Brno: 44.

Radłowska C. 1957. Z badań nad morfogenezą doliny Krępianki. Przegląd Geograficzny 29,2: 359366.

Radłowska C. 1960. Z paleogeomorfologii doliny Zwoleńki. Przeglad Geograficzny 32,4: 561574.

Radłowska C. 1963. Rzeźba północno-wschodniego obrzeżenia Gór Świętokrzyskich. Prace Geograficzne IG PAN 38.

Różycki S.Z. 1964. Klimatostratygraficzne jednostki podziału plejstocenu. Acta Geologica Polonica 14,3: 321-340.

Różycki S.Z. 1967. Plejstocen Polski środkowej na tle przeszłości w górnym trzeciorzędzie. Warszawa.

Różycki S.Z. 1972. Problemy czwartorzędu Gór Świętokrzyskich. Roczniki Polskiego Towarzystwa Geologicznego 42,1: 67-79.

Samsonowicz J. 1925. O granicy zasięgu młodszego zlodowacenia między rzeką Iłżanką a Wisłą. Posiedzenia Naukowe Państwowego Instytutu Geologicznego 12: 9-10.

Samsonowicz J. 1934. Objaśnienia arkusza Opatów. Ogólna mapa geologiczna Polski, PIG 1.

Szczepanek K. 1961. Późnoglacjalna i holoceńska historia roślinności Gór Świętokrzyskich. Acta Palaeobotanica 2(2): 1-44.

Zieliński T. 1998. Litofacjalna identyfikacja osadów rzecznych. W: E. Mycielska-Dowgiałło (red.) Struktury sedymentacyjne $i$ postsedymentacyjne w osadach czwartorzędowych i ich wartość interpretacyjna. UW, Warszawa: 195-257.

Zieliński T. 2014. Sedymentologia osadów rzek i jezior. Wyd. Naukowe UAM, Poznań.

\section{Summary}

The study area is located in southern Poland in the Holy Cross Mts. region. The Kamionka is small, upland and meandering river drained in the northern part of these mountains. It is a tributary of the Kamienna river, which belongs to the
Vistula drainage basin. This entire territory was covered by an ice sheet during the Middle Polish glaciations. Therefore, the present-day river cut its valley in fluvioglacial, sandy series. Some erosional levels occurred. The section of the valley downstream of Suchedniów is narrow, it is a gap between hills built of Triassic sandstones. Two terrace levels could be distinguished here.

The higher terrace in this area reaches 5-12 $\mathrm{m}$ and on this terrace are located two studied profiles, those profiles are located in two different places, $1.5 \mathrm{~km}$ apart. The first one is in the gap section (PK 1) and the second one (PK 2) in the widening of the valley upstream of the gap. Well sorted, sandy channel alluvia of a braided river may be found in both profiles. Sand, and horizontal bedding alluvium covered with blown wind sands with buried soil inside occur in the PK 2 profile located in a non-active sandpit. The structure of the alluvia shows less active fluvial dynamics of a braided river during the formation of an alluvial plain in the wider section of the valley. Sands and gravels with cross bedding and a layer of coarse colluvium (non rounded sandstone rocks) in the upper part of the alluvium occur in the PK 1 profile. This colluvium was created in periglacial conditions by frost weathering, because outcrops of Triassic sandstones are located in the vicinity of the area. This profile shows an interfinger of sediments created by fluvial and slope processes in the narrow gap section of the valley.

Alluvia of 5-12 $\mathrm{m}$ terrace were accumulated by a braided river in the end of Wartanian stadial (Saalian) (TL datings: 127-119 ka). Their texture and structure are different in the narrow and wide section of the valley and were caused by the dynamics of flow and sedimentologic environments. Poligenetic deposits occurring on terrace include: coarse colluvium (Wartha glaciations) inside of the alluvium in the gap section and the aeolian cover (Vistulian and Holocene) on top in the wide section of the valley. 